\title{
Regular Physical Activity and Exercise in Prevention and Management of Diabetes Melitus
}

\author{
Gbonjubola Yusuff Tunde, Ibrahim Ahmad Abubakar* \\ Department of Physiotherapy, Abubakar Tafawa Balewa University Teaching Hospital, Bauchi, NIGERIA.
}

Dear Editor,

Diabetes Mellitus (DM) is a group of metabolic diseases characterized by chronic hyperglycemia resulting from defects in insulin secretion, insulin action, or both. ${ }^{[1]}$ The national Diabetes Data Group (2000) indicated that DM consists of three different types, which include: Type 1, Type 2 and gestational diabetes. ${ }^{[2]}$

Type I DM also used to be referred to as juvenile diabetes or insulindependent diabetes and it is due to the destruction of $\beta$ cells of the pancreas. ${ }^{[3]}$ Also, Type 2 DM was previously referred to as "adult-onset diabetes". It is used to be called non-insulin dependent diabetes or adult-onset diabetes. ${ }^{[4]}$ Here, the pancreas usually produces some insulin, but the insulin might not be enough or the body cells get resistant to it. As such, the body cannot utilize the insulin that is released. ${ }^{[5]}$ However, the third type of diabetes mellitus is the gestational diabetes, and it occurs when pregnant women without a previous history of diabetes develop high blood sugar levels. ${ }^{[6]}$

According to International Diabetes Federation (IDF), 382 million (or 8.3\% of adult world population) people worldwide have diabetes mellitus as at 2013. The prevalence of diabetes in Nigeria ranges from low level of $0.8 \%$ among adults in rural highland dwellers to over $7 \%$ in urban areas like Lagos with an average of $2.2 \%$ nationally. ${ }^{[7]}$ However, in another study by Owoaje et al. The prevalence of diabetes in a community sample of 247 men and women in Ibadan, following a simple random sampling technique was $2.8 \% \cdot{ }^{[8]}$

Physical activity includes all movement that increases energy use, whereas exercise is planned, structured physical activity. Exercise improves blood glucose control in type 2 diabetes, reduces cardiovascular risk factors, contributes to weight loss, and improves well-being. ${ }^{\left[{ }^{9]}\right.}$ Different exercise programed has significant effect on health. For instance, flexibility exercises improve range of motion around joints. ${ }^{[10]}$ Also, balance exercises help with proper gait and prevent falls ${ }^{[11]}$ and can also reduce falls risk by improving balance and gait, even when peripheral neuropathy is present. ${ }^{[1]]}$ Moreso, stretching increases range of motion around joints and flexibility ${ }^{10}$ but does not affect glycemic control.

Regular exercise may prevent or delay type 2 diabetes development. ${ }^{[12]}$ It also has considerable health benefits for people with type 1 diabetes (e.g., improved cardiovascular fitness, muscle strength and insulin sensitivity. ${ }^{[13]}$ Regular Physical activity is beneficial and does not lead to any adverse effects to individuals including pregnant women ${ }^{[14]}$ and patients with asthma. ${ }^{[15]}$ Physical activity and exercise recommendations therefore, should be tailored to meet the specific needs of each individual.

In conclusion, Physical activity and exercise programme have shown to be of significant importance in prevention and management of diabetes mellitus. Exercise programme for patient with diabetes must be well structured, carefully prescribed, gradually progressed and closely monitored which is only possible with exercise experts.

\section{REFERENCES}

1. Franklin BE, Crisler SC, Shappley R, Armour MM, McCommon DT, Ferry RJ. Real-time support of pediatric diabetes self-care by a transport team. Diabetes Care. 2014;37(1):81-7. doi: 10.2337/dc13-1041. PMID 23959568.

2. National Diabetes Data Group. Classification and diagnosis of diabetes mellitus and other categories of glucose intolerance. Diabetes. 1979;28(12):1039-57. doi: 10.2337/diab.28.12.1039.

3. Daneman D. Type1 diabetes. Lancet. 2006;367(9513):847-58. doi: 10.1016/ S0140-6736(06)68341-4, PMID 16530579.

4. International Diabetes Federation; 2014. IDF diabetes atlas. 8th ed [cited Jul 14, 2019]. Available from: http://www.idf.org/diabetesatlas.

5. Canadian Diabetes Association. Pharmacologic glycemic management of Type 2 diabetes in Adults 2019.

6. Genuth S, Alberti KG, Bennett P, Buse J, Defronzo R, Kahn R, Kitzmiller J, Knowler WC, Lebovitz H, Lernmark A, Nathan D, Palmer J, Rizza R, Saudek C, Shaw J, Steffes M, Stern M, Tuomilehto J, Zimmet P, Expert Committee on the Diagnosis and Classification of Diabetes Mellitus. Follow-up report on the diagnosis of diabetes mellitus. Diabetes Care. 2003;26(11):3160-7. doi: 10.2337/ diacare.26.11.3160, PMID 14578255.

7. Dahiru T, Aliyu A, Shehu AU. A review of population-based studies on diabetes mellitus in Nigeria. Sub-Saharan Afr J Med. 2016;3(2):59-64. doi: 10.4103/23845147.184351

8. Owoaje EE, Rotimi CN, Kaufman JS, Tracy JA, Cooper RS. Prevalence of adult diabetes in Ibadan, Nigeria. East Afr Med J. 1997;74(5):299-302. PMID 9337007.

9. Chen L, Magliano DJ, Zimmet PZ. The worldwide epidemiology of type 2 diabetes mellitus--present and future perspectives. Nat Rev Endocrinol. 2011;8(4):228-36. doi: 10.1038/nrendo.2011.183, PMID 22064493.

10. Herriott MT, Colberg SR, Parson HK, Nunnold T, Vinik Al. Effects of 8 Weeks of Flexibility and Resistance Training in Older Adults With Type 2 Diabetes. Diabetes Care. 2004;27(12):2988-9. doi: 10.2337/diacare.27.12.2988.

11. Morrison S, Colberg SR, Mariano M, Parson HK, Vinik AI. Balance training reduces falls risk in older individuals with type 2 diabetes. Diabetes Care. 2010;33(4):748-50. doi: 10.2337/dc09-1699, PMID 20097781.

12. Schellenberg ES, Dryden DM, Vandermeer B, Ha C, Korownyk C. Lifestyle interventions for patients with and at risk for type 2 diabetes: a systematic review and meta-analysis. Ann Intern Med. 2013;159(8):543-51. doi: 10.7326/0003-4819159-8-201310150-00007, PMID 24126648.

13. Yardley JE, Hay J, Abou-Setta AM, Marks SD, McGavock J. A systematic review and meta-analysis of exercise interventions in adults with type 1 diabetes. Diabetes Res Clin Pract. 2014;106(3):393-400. doi: 10.1016/j.diabres.2014.09.038, PMID 25451913.

14. Abubakar IA. Regular physical activity during pregnancy improves maternal depressive symptoms. J Pharm Pract. Commun Med. 2021;7(1):17.

15. Abubakar IA, Shitu AA, Muhammed J. Relationship between the knowledge of benefit of physical activity and physical activity level among individuals with asthma in Kano State, Nigeria. J Pharm Pract. Commun Med. 2019;5(3):54-7. 
Tunde and Abubakar: Regular PA/Exercise and Diabetes

Received: 22 April 2021;

Accepted: 27 June 2021

*Correspondence to:

PT. Ibrahim Ahmad Abubakar (BPT),

Department of Physiotherapy, Abubakar Tafawa Balewa University Teaching Hospital, Bauchi, NIGERIA.

Phone no +2348029819190 Email: ibrahimcsskd@gmail.com

Copyright: (C) the author(s),publisher and licensee Indian Academy of Pharmacists. This is an open-access article distributed under the terms of the Creative Commons Attribution Non-Commercial License, which permits unrestricted non-commercial use, distribution, and reproduction in any medium, provided the original work is properly cited. 